\title{
SUSCEPTIBILITY OF RATS TO EXPERIMENTAL PYELONEPHRITIS FOLLOWING RECOVERY FROM POTASSIUM DEPLETION * $\dagger$
}

\author{
By JAMES W. WOODS, LOUIS G. WELT, WALTER HOLLANDER, JR.革 AND \\ MARGARET NEWTON §
}

(From the Department of Medicine, University of North Carolina School of Medicine, Chapel Hill, N. C.)

(Submitted for publication April 15, 1959; accepted September 10, 1959)

Ureteral ligation (1-3), mechanical trauma (4, $5)$, scar formation in the kidney after recovery from severe staphylococcal infection (6), localized thermal injury to the renal medulla $(7)$, and renal lesions induced by desoxycorticosterone acetate (DCA)-saline hypertension $(8,9)$ have been shown to predispose to the development of acute, hematogenous, Escherichia coli pyelonephritis in the experimental animal. It is established that potassium depletion produces renal lesions in experimental animals and in man $(10,11)$. A temporary deficiency of potassium has been shown to lead to permanent renal damage in the rat despite subsequent repletion $(12,13)$. However, the degree of renal damage was quite dissimilar in the two studies, which has raised the possibility that spontaneous pyelonephritis may have complicated the findings in the one of these studies in which observations were not made to exclude it (12). Clinical data suggest an association between potassium nephropathy and pyelonephritis but this remains only suggestive $(14,15)$. There is evidence both for (15) and against such an association in the experimental animal $(13,16)$. The present investigation was therefore designed to test, by experiment, the hypothesis that animals which have recovered from potassium depletion may have increased susceptibility to pyelonephritis. The problem of susceptibility to infection during potassium depletion is under current investigation.

* This investigation was supported in part by a grant from the Life Insurance Medical Research Fund, by Grant H-1301 from the United States Public Health Service, Bethesda, Md., and by a grant from the American Heart Association.

$\dagger$ Presented at the annual meeting of the Interurban Clinical Club, Chapel Hill, N. C., April 3, 1959.

$\$$ Markle Scholar in Medical Science.

$\S$ Postdoctoral Research Fellow of the National Foundation.

\section{MATERIALS AND METHODS}

White, male Sprague-Dawley strain rats, weighing 128 to $160 \mathrm{Gm}$., were used. Potassium depletion was accomplished by means of a basal diet which was deficient in potassium, sodium, phosphate and chloride. Control groups received the following daily quantity of supplementary electrolytes by gavage: $5 \mathrm{cc}$. of gavage solution containing $2 \mathrm{mk}$ oles of potassium, $2 \mathrm{mMoles}$ of sodium, 2.5 mMoles of chloride and $0.75 \mathrm{mMole}$ of phosphate. The potassium-deficient group received $4 \mathrm{mMoles}$ of sodium, 2 mMoles of bicarbonate, $0.5 \mathrm{mMole}$ of chloride and $0.75 \mathrm{mMole}$ of phosphate. The method of producing potassium depletion, including content of diet as well as the chemical determinations used, has been previously described (17). The animals were "pair-fed" by groups, i.e., the intake of the control groups was limited each day to the average intake of the experimental groups. After having been on a potassium-deficient regimen for four weeks, Groups B and C were given Purina ${ }^{\circledR}$ Laboratory Chow and distilled water ad libitum for the next six to seven months. The final average weight of the experimentals was $460 \mathrm{Gm}$. while the final average weight of the controls was $485 \mathrm{Gm}$.

Bacteriological technique. The strain of $E$. coli used for intravenous inoculation had been isolated from the urine of a patient with active pyelonephritis, identified, injected intravenously into a rat with a ligated ureter, subsequently recovered from the infected kidney, and inoculated into tubes containing $10 \mathrm{ml}$. of sterile broth. The tubes were incubated for three hours, sealed with parafilm, frozen and stored at $-20^{\circ} \mathrm{C}$. Colony counts had been plotted against Klett-Summerson colorimeter readings on a broth culture at frequent intervals in order to simplify the determination and standardization of inoculum size for future experiments. A few days before the rats of Group $\mathrm{C}$ were to be injected with $E$. coli, a frozen culture was warmed to $37^{\circ} \mathrm{C}$., incubated for 12 hours, and a small inoculum placed in $150 \mathrm{ml}$. of sterile broth. When growth produced marked turbidity, the culture was diluted with sterile broth to the desired colorimeter reading, i.e., equivalent to the number of million bacteria injected. Then 20 to $25 \mathrm{ml}$. was removed, centrifuged and the sediment resuspended in an equivalent volume of sterile saline. One $\mathrm{ml}$. of this saline suspension, calculated to contain approximately $100,000,000 \mathrm{E}$. coli, was injected into the tail veins of three rats, each with a ligated ureter. After an interval 
of four days, these rats were sacrificed, the organism recovered, identified, incubated in sterile broth for approximately six hours, diluted with sterile broth to the desired colorimeter reading, the organism resuspended in saline, and $1 \mathrm{ml}$. of this saline suspension injected into the tail veins of the animals of Group C. The actual number of bacteria injected was $105,000,000$ by colony count. Further details of bacteriological techniques have been previously described (8).

Experimental design. The experimental design is shown in Table I. Group A was sacrificed after four weeks for documentation of the degree of potassium depletion and of the resultant histological changes. Group B animals were sacrificed six months after potassium repletion for analysis of renal histology, potassium content of skeletal muscle and culture for spontaneous infection. The rats of Group $\mathrm{C}$ were injected intravenously with E. coli seven months after potassium repletion. They were arbitrarily sacrificed on either the eighth or ninth day after injection.

One of the control animals died 24 hours after injection. Since it had been dead for an indefinite time before discovery and since this is an insufficient time for
TABLE I

Experimental design

\begin{tabular}{clcc}
\hline \hline Group & \multicolumn{1}{c}{ Description } & $\begin{array}{c}\text { No. of } \\
\text { experi- } \\
\text { mental } \\
\text { rats }\end{array}$ & $\begin{array}{c}\text { No. of } \\
\text { control } \\
\text { rats }\end{array}$ \\
\hline A & $\begin{array}{l}\text { K depletion 4 weeks. } \\
\text { Analysis of renal } \\
\text { histology, serum } \\
\text { electrolytes, muscle K, } \\
\text { culture for spontaneous } \\
\text { infection. }\end{array}$ & 5 & 5 \\
B & $\begin{array}{l}\text { K depletion 4 weeks. } \\
\text { Repletion 6 months. } \\
\text { Analysis of renal his- } \\
\text { tology, muscle K, culture } \\
\text { for spontaneous infection. }\end{array}$ & 5 & 5 \\
C & $\begin{array}{l}\text { K depletion 4 weeks. } \\
\text { Repletion 7 months. } \\
\text { 105,000,000 E. coli } \\
\text { I.V. }\end{array}$ \\
\hline
\end{tabular}

the development of gross or microscopic lesions of pyelonephritis, it was eliminated from the study.

TABLE II

Groups $A$ and B-Analyses of sera and skeletal muscle

\begin{tabular}{|c|c|c|c|c|c|c|c|}
\hline \multicolumn{6}{|c|}{ Serum } & \multicolumn{2}{|c|}{ Muscle } \\
\hline & $\mathrm{Na}$ & $\mathrm{K}$ & $\mathrm{Cl}$ & $\mathrm{CO}_{2}$ & BUN & $\mathrm{H}_{2} \mathrm{O}$ & $\mathrm{K}$ \\
\hline \multicolumn{8}{|c|}{ Acute $K$ depletion-Group $A$} \\
\hline & $\begin{array}{l}147.0 \\
143.0 \\
145.0 \\
145.5 \\
151.5\end{array}$ & $\begin{array}{l}2.4 \\
2.4 \\
2.8 \\
2.3 \\
2.3\end{array}$ & $\begin{array}{l}69.8 \\
83.1 \\
89.2 \\
70.8 \\
67.8\end{array}$ & $\begin{array}{l}48.0 \\
37.4 \\
37.0 \\
48.3 \\
31.7\end{array}$ & & $\begin{array}{l}327 \\
322 \\
319 \\
313 \\
323\end{array}$ & $\begin{array}{l}27.1 \\
29.4 \\
27.9 \\
26.9 \\
27.4\end{array}$ \\
\hline \multicolumn{8}{|l|}{ Controls } \\
\hline & $\begin{array}{l}145.0 \\
149.5 \\
145.3\end{array}$ & $\begin{array}{l}4.8 \\
5.4 \\
5.1\end{array}$ & $\begin{array}{l}106.4 \\
104.0 \\
101.7\end{array}$ & $\begin{array}{l}15.8 \\
26.0 \\
22.3\end{array}$ & & $\begin{array}{l}334 \\
330 \\
324 \\
327\end{array}$ & $\begin{array}{l}46.5 \\
46.2 \\
45.5 \\
42.5\end{array}$ \\
\hline & 143.8 & 5.8 & 101.7 & 21.0 & & 337 & 46.4 \\
\hline \multicolumn{8}{|c|}{$K$-depleted with long-term repletion-Group B } \\
\hline & $\begin{array}{l}146.8 \\
142.5 \\
145.2 \\
144.9 \\
143.4\end{array}$ & $\begin{array}{l}4.8 \\
4.6 \\
4.4 \\
4.5 \\
4.1\end{array}$ & $\begin{array}{r}100.5 \\
93.8 \\
100.5 \\
98.5 \\
99.3\end{array}$ & $\begin{array}{l}24.6 \\
28.9 \\
25.0 \\
28.7 \\
23.3\end{array}$ & $\begin{array}{l}26 \\
22 \\
21 \\
23 \\
24\end{array}$ & $\begin{array}{l}318 \\
318 \\
325 \\
325 \\
332\end{array}$ & $\begin{array}{l}44.4 \\
44.5 \\
46.5 \\
46.2 \\
46.2\end{array}$ \\
\hline \multicolumn{8}{|l|}{ Controls } \\
\hline & 143.0 & 4.6 & 98.8 & 20.9 & 21 & 313 & 46.0 \\
\hline & $\begin{array}{l}146.0 \\
142.7 \\
147.8\end{array}$ & $\begin{array}{l}4.5 \\
4.3 \\
4.8\end{array}$ & $\begin{array}{r}100.0 \\
95.3 \\
98.5\end{array}$ & $\begin{array}{l}21.6 \\
28.4\end{array}$ & $\begin{array}{l}21 \\
24\end{array}$ & $\begin{array}{l}316 \\
317 \\
320\end{array}$ & $\begin{array}{l}47.9 \\
47.4 \\
46.2\end{array}$ \\
\hline
\end{tabular}

*FFDS $=$ fat-free dry solids. 


\section{RESULTS}

\section{Group $A$}

The results of potassium depletion for four weeks in the animals of Group A are shown in Table II. Analyses of serum electrolytes as compared with their controls show a marked hypokalemic, hypochloremic alkalosis. Serum sodium remained nor- mal. There was a marked decrease in skeletal muscle potassium content when measured in terms of milliequivalents of potassium per $100 \mathrm{Gm}$. of fat-free dry solids. Histological study of the kidneys of these animals revealed the characteristic cellular alterations in the tubules expected in acute, severe potassium depletion. These tubular lesions,
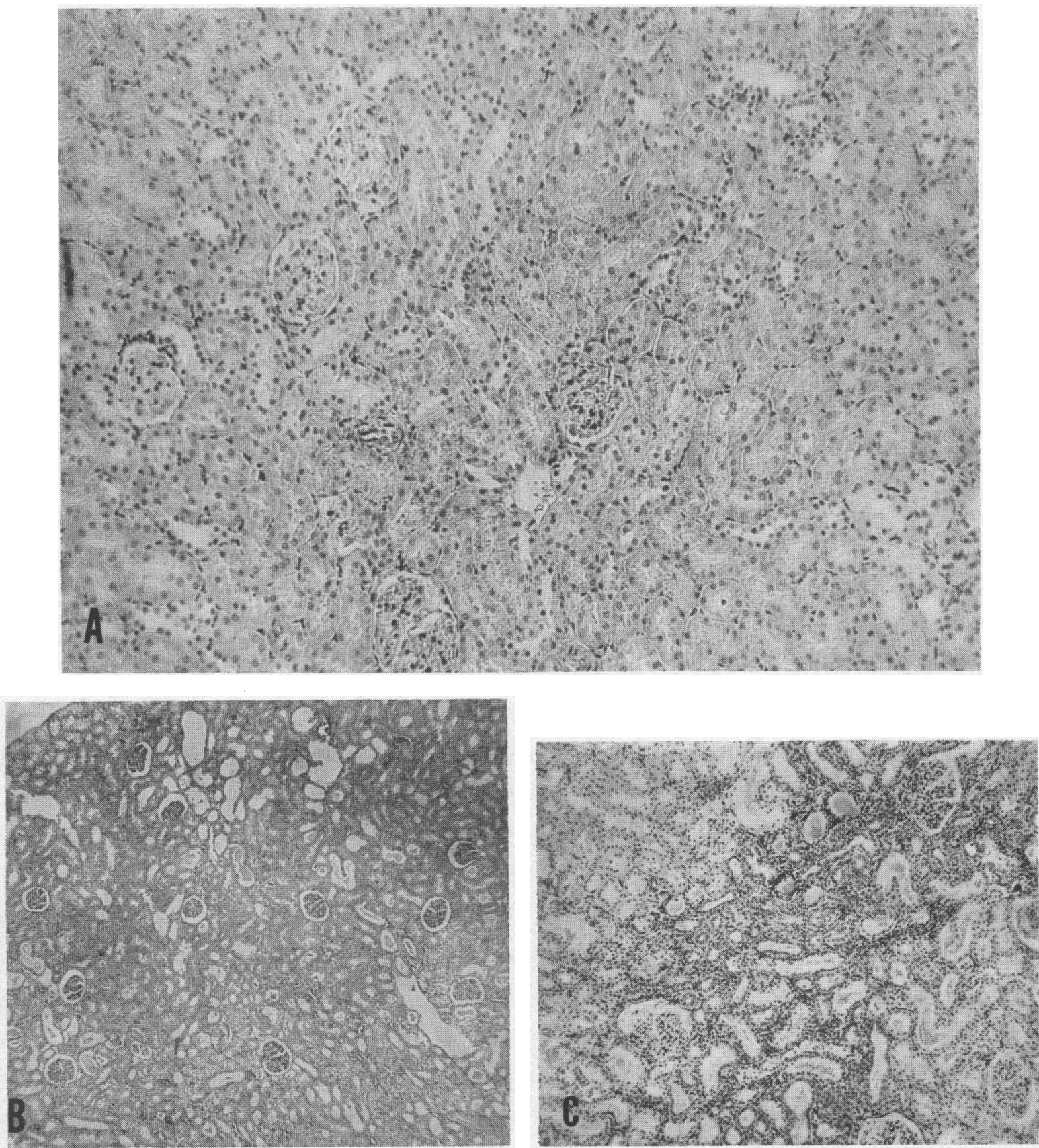

FIg. 1-Continued 

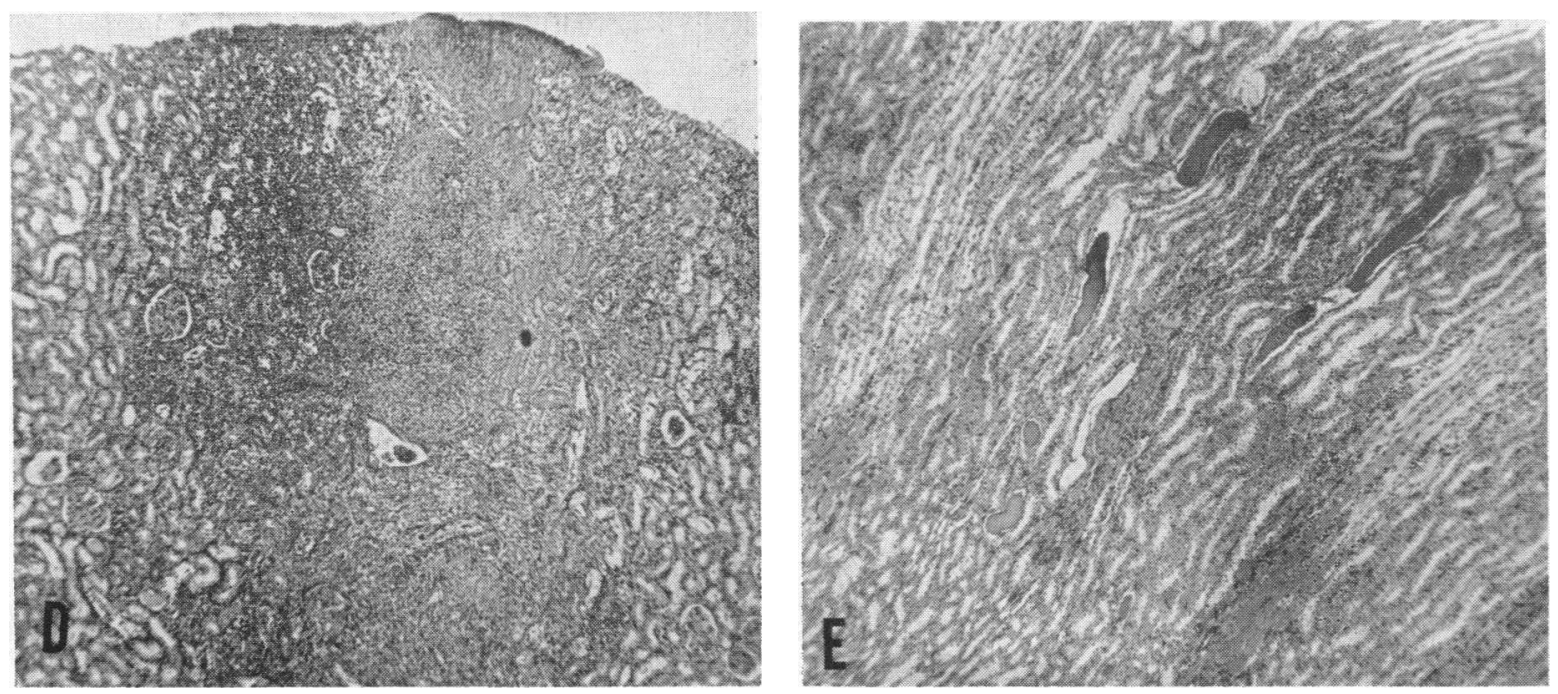

Fig. 1. Illustrations of Normal and Pathologic Histology Encountered

A. Normal rat kidney $(\times 115)$. B. Kidney from a Group A rat after four weeks of potassium depletion. There are many dilated tubules containing homogenous material $(\times 75)$. C. Infiltration of mononuclear cells in the Group $\mathrm{C}$ control whose kidneys were sterile on culture $(\times 75)$. D. Renal cortical abscess $(\times 75)$. E. Kidney from a Group B rat. Potassium repletion for six months. Scattered tubular dilatation is present $(\times 75)$. Hematoxylin and eosin.

the renal lesions after long-term repletion (Group $B)$, and the changes of superimposed pyelonephritis, are illustrated in Figure 1.

\section{Group B}

The five rats in this group, which received a stock diet adequate in potassium for six months following a four week period of potassium depletion, had normal serum electrolytes, blood urea nitrogen and muscle potassium (Table II). Their kidneys appeared larger than control kidneys and contained structural abnormalities consisting of dilated tubules containing eosinophilic casts. However, in comparison with the severe residual pathology reported by Fourman, McCance and Parker (12), the lesions were rather minor.

\section{Group C}

The 14 experimental rats in this group were treated the same as those in Group B except that the period of potassium repletion was of seven months' duration rather than six, for technical reasons. They were injected with $105,000,000$ $E$. coli and sacrificed in eight to nine days. Of the 14, 9 had both cultural and microscopic evidence of pyelonephritis while a tenth had a colony count of $1,920,000$ bacteria per $\mathrm{Gm}$. of kidney tissue, but no microscopic evidence of infection (Table III). Seven had macroscopic abscesses in one or both kidneys.

Of the 13 controls, 2 had cultural, but no microscopic evidence of pyelonephritis, while a third had microscopic evidence of infection, but the kidneys were sterile on culture.

TABLE III

Group C-Colony count and descriptions of kidneys, after injection of E. coli ${ }^{*}$, of experimental animals seven months after potassium depletion, and of control animals

\begin{tabular}{cccc}
\hline \hline $\begin{array}{c}\text { Kidney of } \\
\text { K-depleted }\end{array}$ & $\begin{array}{c}\text { Descrip- } \\
\text { tiont }\end{array}$ & $\begin{array}{c}\text { Kidney of } \\
\text { control }\end{array}$ & $\begin{array}{c}\text { Descrip- } \\
\text { tiont }\end{array}$ \\
\hline $3,700,000 \ddagger$ & + & 0 & + \\
$150,000 \ddagger$ & + & 0 & 0 \\
31,000 & +++ & 0 & 0 \\
970,000 & +++ & 0 & 0 \\
0 & 0 & $1,200,000$ & 0 \\
0 & 0 & 0 & 0 \\
400,000 & +++ & 0 & 0 \\
23,800 & +++ & 0 & 0 \\
0 & 0 & 0 & 0 \\
960,000 & +++ & 0 & 0 \\
100,000 & +++ & 0 & 0 \\
530,000 & +++ & 0 & 0 \\
0 & 0 & $75,000 \ddagger$ & 0 \\
$1,920,000$ & 0 & &
\end{tabular}

\footnotetext{
* Inoculum $=105,000,000$ organisms.
}

$\dagger 0$, no cellular infiltrate; + , cellular infiltrate; ++ , microscopic abscesses; +++ , macroscopic abscesses.

$\ddagger$ Lung abscess also due to $E$. coli. 
Two of the experimentals and one of the controls also had lung abscesses due to $E$. coli. No other sites of extrarenal infection were found.

In summary, 10 of 14 previously potassium-depleted rats, but only 3 of 13 controls, developed varying degrees of pyelonephritis $(p<0.05){ }^{1}$

\section{DISCUSSION}

There is a convincing body of evidence that obstruction to urine flow, whether in the kidney or in the lower urinary tract, predisposes to infection. The residual damage following an episode of acute potassium depletion is characterized by dilated tubules which are presumably obstructed (13). Therefore, it is not surprising that previously potassium-depleted rats have increased susceptibility to renal infection.

The decision as to whether a given kidney is infected presents no problem when a high colony count of bacteria is combined with gross abscesses or microscopic evidence of pyelonephritis. The decision is quite difficult when there is only a borderline colony count or cellular infiltrate in a kidney which is sterile bacteriologically. In Group C, 7 of 14 repleted rats had macroscopic abscesses. Abscesses were present in none of the 13 controls. Two of the repleted rats had kidneys containing heavy infiltrates of mononuclear cells accompanied by colony counts of 3,700,000 and $150,000 \mathrm{E}$. coli per Gm. of kidney. Since cellular infiltration was not seen in uninjected, repleted animals (Group $B$ ) and since these are higher colony counts than are to be expected in normal kidneys after this interval (3), they were considered infected. The kidneys of one repleted animal and two controls had counts of 1,920,000, 1,200,000 and 75,000, but no microscopic evidence of pyelonephritis. However, the lesions of pyelonephritis are often quite small and discrete and may therefore be missed when only one or two sections are made from a kidney. Also, since one-half of each kidney was homogenized for culture while the other half was fixed for microscopic study, it was possible to have localized infection in only the half which was cultured. One control animal had a heavy cellular infiltrate, but was sterile on culture. These four animals were considered to be infected, but

\footnotetext{
1 A chi-square test was used to calculate $\mathrm{p}$ values.
}

even if they are considered negative, the overall conclusions are not significantly affected.

The susceptibility of rats to renal infection during acute potassium nephropathy was also studied (18), but since the number of animals was small and the results inconclusive, this problem is being made the subject of further investigation.

This study not only lends support to the clinical observations that potassium deficiency predisposes to renal infections $(14,15)$, but also raises the question of whether an episode of potassium depletion in humans may permanently increase susceptibility to pyelonephritis.

\section{SUM MARY}

Rats with renal lesions resulting from a previous episode of potassium depletion have been shown to exhibit increased susceptibility to experimental pyelonephritis. The factor responsible for this increased susceptibility is unknown, but is most likely tubular obstruction or "internal hydronephrosis."

\section{REFERENCES}

1. Lepper, E. H. The production of coliform infection in the urinary tract of rabbits. J. Path. Bact. 1921, 24, 192.

2. Mallory, G. K., Crane, A. R., and Edwards, J. E. Pathology of acute and of healed experimental pyelonephritis. Arch. Path. (Chicago) 1940, 30, 330.

3. Guze, L. B., and Beeson, P. B. Experimental pyelonephritis. I. Effect of ureteral ligation on the course of bacterial infection in the kidney of the rat. J. exp. Med. 1956, 104, 803.

4. Brewer, G. E. The present state of our knowledge of acute renal infections. With a report of some animal experiments. J. Amer. med. Ass. 1911, 57, 179.

5. Braude, A. I., Shapiro, A. P., and Siemienski, J. Hematogenous pyelonephritis in rats. I. Its pathogenesis when produced by a simple new method. J. clin. Invest. 1955, 34, 1489.

6. De Navasquez, S. Further studies in experimental pyelonephritis produced by various bacteria, with special reference to renal scarring as a factor in pathogenesis. J. Path. Bact. 1956, 71, 27.

7. Beeson, P. B., Rocha, H., and Guze, L. B. Experimental pyelonephritis. Influence of localized injury in different parts of the kidney on susceptibility to hematogenous infection. Trans. Ass. Amer. Phycns 1957, 70, 120.

8. Woods, J. W. Susceptibility of rats with hormonal hypertension to experimental pyelonephritis. J. clin. Invest. 1958, 37, 1686.

9. Shapiro, A. P. Relationships of hypertension and 
renal impairment to experimental chronic pyelonephritis in rats (abstract). J. clin. Invest. 1958, 37, 930.

10. Relman, A. S., and Schwartz, W. B. The nephropathy of potassium depletion. A clinical and pathological entity. New Engl. J. Med. 1956, 255, 195.

11. Oliver, J., MacDowell, M., Welt, L. G., Holliday, M. A., Hollander, W., Jr., Winters, R. W., Williams, T. F., and Segar, W. E. The renal lesions of electrolyte imbalance. I. The structural alterations in potassium-depleted rats. J. exp. Med. 1957, 106, 563.

12. Fourman, P., McCance, R. A., and Parker, R. A. Chronic renal disease in rats following a temporary deficiency of potassium. Brit. J. exp. Path. 1956, $37,40$.

13. Hollander, W., Jr., Winters, R. W., Bradley, J., Williams, T. F., Loring, W. E., Oliver, J., and Welt, L. G. The effect of potassium repletion on the renal-concentrating defect, the renal structural changes, and the cardiac and skeletal muscle.le- sions produced by potassium depletion in rats (abstract). Clin. Res. 1958, 6, 287.

14. Milne, M. D., Muehrcke, R. C., and Heard, B. E. Potassium deficiency and the kidney. Brit. med. Bull. 1957, 13, 15.

15. Muehrcke, R. C., and Milne, M. D. Primary hyperaldosteronism, long-standing potassium depletion, and pyelonephritis (abstract). Clin. Res. 1957, 5, 190.

16. Carone, F. A., Kashgarian, M., and Epstein, F. H. Failure of potassium deficiency to induce susceptibility to renal infection: An experimental and autopsy study. Clin. Res. 1958, 6, 286.

17. Hollander, W., Jr., Winters, R. W., Williams, T. F., Bradley, J., Oliver, J., and Welt, L. G. Defect in the renal tubular reabsorption of water associated with potassium depletion in rats. Amer. J. Physiol. 1957, 189, 557.

18. Woods, J. W., Welt, L. G., Hollander, W., Jr., and Newton, M. Susceptibility to experimental pyelonephritis during and after potassium depletion (abstract). J. clin. Invest. 1959, 38, 1056. 